\title{
COMPARISON OF EFFICIENCY AND CARBON EMISSIONS OF FILAMENT ELECTRIC STOVES AND INDUCTION ELECTRIC STOVES
}

\author{
Anisa Indriawati ${ }^{1}$, Aning K. Putri ${ }^{2}$, Yunita Febriani ${ }^{1}$, Lizia Miratsi ${ }^{1}$, Fitri Afriani ${ }^{1}$ dan \\ Yuant Tiandho, ${ }^{1, *}$ \\ ${ }^{1}$ Department of Physics, Universitas Bangka Belitung, Bangka, Kep. Bangka Belitung 33172, \\ Indonesia \\ ${ }^{2}$ Department of Economy, Universitas Bangka Belitung, Bangka, Kep. Bangka Belitung 33172, \\ Indonesia
}

\begin{abstract}
Issues related to energy sustainability and carbon emission reduction are continuously being concerned by the Government of the Republic of Indonesia. Various efforts and programs have been launched to achieve targets of the related issues. As known that energy use for cooking by the household is continuously increasing in relation to population growth that will off course increase in energy need which relate to sustainability of presence energy and carbon emission. Accordingly, the LPG stove conversion program to an electric stove was introduced in order to achieve the target to solve such issues. This paper compared of efficiency and carbon emissions of both electric filament stove and induction stove. The result indicated that the induction stove have better efficiency compared with the electric stove. The study also was proved that the carbon emissions for both types of stoves were relatively low in comparison with LPG stove. However, the enormous operational power of the induction stove is still a challenge that must be resolved to achieve the target of energy sustainability in Indonesia.
\end{abstract}

Keywords: Electrical stoves; Induction stoves; Carbon emission; Clean technology.

\section{Introduction}

Reducing carbon gas emissions is currently a central issue that has become the main problem in various countries. It relates to an important strategy to minimize the impact of climate change worldwide based on the Copenhagen climate conference. ${ }^{1,2}$ Various programs/activities have been proposed to overcome these problems, ${ }^{3}$ such as efforts to increase the use of renewable energy, ${ }^{4}$ development of high-efficiency equipment, and management of energy use at small to mass levels. ${ }^{5-7}$ In addition to the transportation and industrial sectors, the household sector is one sector that requires a significant amount of energy in Indonesia. In 2019, the household sector accounted for $14 \%$ of national energy use, with a projected increase of $4 \%$ per year.

On the other hand, the energy consumed by the household sector can contribute to carbon

\footnotetext{
*Corresponding author.

E-Mail: yuanttiandho@gmail.com
}

emissions such as $\mathrm{CO}_{2}$, especially from the use of cooking fuel. ${ }^{7,8}$ Several types of fuel widely used by people in Indonesia are liquefied petroleum gas (LPG), firewood, charcoal, and kerosene. Among these fuels, LPG has the lowest $\mathrm{CO}_{2}$ emission factor value of $63,100 \mathrm{~kg} / \mathrm{TJ}$ with a net calorific value of $47.3 \times 10-6 \mathrm{TJ} / \mathrm{kg} .{ }^{8}$ However, the percentage of use reaching $72.38 \%$ of the entire population of Indonesia, the amount of $\mathrm{CO} 2$ produced also has a significant value. ${ }^{9}$ Therefore, in recent years several elements of the Government of the Republic of Indonesia have begun to aggressively initiate the conversion of LPG gas stoves to electric stoves. ${ }^{10,11}$ Electric stoves can reduce carbon emissions during cooking and are more efficient than LPG stoves. ${ }^{12-14}$ However, there are currently at least two electric stoves on the market: filament electric stoves and induction 
stoves. Unlike electric stoves, which generate heat due to resistance when current passes through the filament element, induction cookers generate heat due to magnetic field oscillations that induce cooking equipment made of ferromagnetic materials. ${ }^{15}$ In this article, a comparison of the efficiency and carbon emissions of filament electric stoves and induction cookers is carried out. It aims to provide a more comprehensive picture of the characteristics of the two electric stoves. In addition, this article is a development of research by Hasanah and Handayani (2016), who have previously compared the two stoves. ${ }^{16}$ However, the work that has been done has not involved an analysis of carbon emissions and how efficient the stove is for different scales of use. In addition, it is hoped that this information can be used to develop low-power induction cookers to expand the application of induction cookers for people with low-power groups.

\section{Method}

By using experiment method, the research was conducted to measure and compare the efficiency of filament and induction stove. The filament electric stove used in this study has a maximum working power of 600 Watts with a cooking level of 1 to 5. In comparison, the induction cooker used in this study is an induction stove with a maximum working power of 1600 Watt. The tests were carried out at cooking levels 3 and 5 on a filament electric stove while on an induction cooker at a condition of $500^{\circ} \mathrm{C}$ (middle level) and $1300^{\circ} \mathrm{C}$ (upper level). Comparing the efficiency of the filament electric stove and the induction cooker is done by comparing the energy consumed by the two stoves during the cooking process. Two cooking activities use the two stoves: (i) boiling one liter of water until it boils and (ii) frying chicken nuggets: (i) boiling one liter of water until it boils and (ii) frying chicken nuggets. The process of boiling water is carried out from room temperature $\left(26^{\circ} \mathrm{C}\right)$ to boiling $\left(100^{\circ} \mathrm{C}\right)$. Chicken nuggets used in this study are commercial nuggets that can be purchased in the market. Frying nuggets is carried out on both stoves with the same number and mass of nuggets. To find out the energy consumed by the stove during the cooking process is carried out with an energy-meter with a scheme as shown in Figure 1. The parameters observed from the efficiency study include energy consumed, average power during cooking, and cooking time.

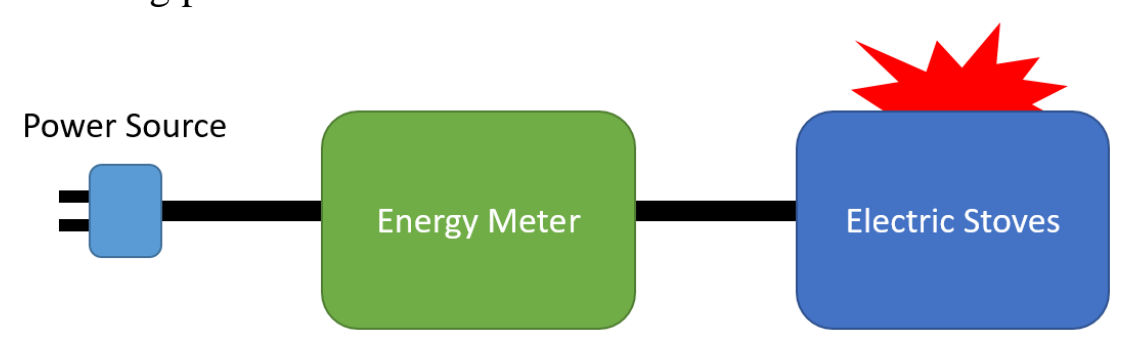

Figure 1. Schematic of measuring the energy consumed on the electric stove

The measurement of carbon emissions was carried out for two types of carbon emissions that often appear in the cooking process, namely $\mathrm{CO}_{2}$ emissions (carbon dioxide) and $\mathrm{CO}$ emissions (carbon monoxide). The scheme for measuring $\mathrm{CO}_{2}$ and $\mathrm{CO}$ emissions during the cooking process is carried out in a room equipped with a gas trapping system, as shown in Figure 2. The smoke collector is equipped with an aluminum chimney with a fan installed at the chimney's mouth. The $\mathrm{CO}_{2}$ detector (Smart Sensor - AR8200) and CO detector (Benetech - GM8805) are placed in the smoke storage room to determine carbon emissions during the cooking process. 


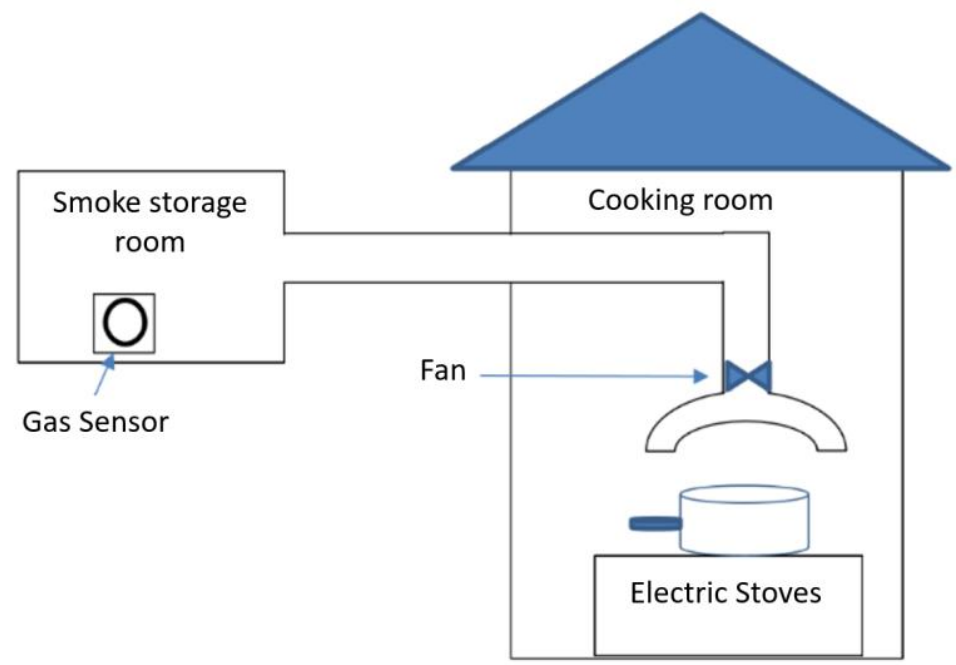

Figure 2. Schematic of measuring carbon emissions during the cooking process

\section{Result and Discussion}

Table 1 shows the average power of filament electric stoves and induction cookers for boiling water and frying nuggets. It appears that the induction cooker requires more power than the filament electric stove. Even at the intermediate level of cooking using an induction cooker $\left(500^{\circ} \mathrm{C}\right)$, the power used is still more significant than the enormous scale filament electric stove. Therefore, based on the high power required to operate an induction cooker, this might be a consideration for the Government of the Republic of Indonesia when it wants to launch a conversion program for LPG gas stoves to electric stoves, especially for induction cookers. It is because the majority of Indonesian people still be a customer of PT. PLN (Persero) for the low-class level (R-1) ${ }^{17}$. In addition, the high power consumed by induction cookers can be an opportunity for further research related to the development of induction cookers with low power levels.

Table 1. Comparison of the average power of induction power stove when operated

\begin{tabular}{lcccc}
\hline \multirow{2}{*}{ Cooking activities } & \multicolumn{4}{c}{ Average power (Watt) } \\
\cline { 2 - 5 } & $\begin{array}{c}\text { Filament Stove- } \\
\text { Filament }\end{array}$ & $\begin{array}{c}\text { Induction } \\
\text { Stove-5 }\end{array}$ & $\begin{array}{c}\text { Induction } \\
\text { Stove-500 }\end{array}$ & Stove-1300 \\
\hline Boiling water (1 liter) & 320 & 591 & 900 & 1410 \\
Frying nuggets & 278 & 544 & 870 & 1500 \\
\hline
\end{tabular}

In Table 2, a comparison of the cooking time between using a filament electric stove and an induction stove. It appears that the induction stove with a heating rate of $1300^{\circ} \mathrm{C}$ is faster than the other. In addition, the induction stove with a medium heating rate $\left(500^{\circ} \mathrm{C}\right)$ is also faster than the filament electric stove, even with the highest heating level. These results indicate that the efficiency level of cooking time using an induction stove is better than that of a filament electric stove.

Table 2. Comparison of cooking time

\begin{tabular}{lcccc}
\hline \multirow{2}{*}{ Cooking activities } & \multicolumn{4}{c}{ Cooking time (min.) } \\
\cline { 2 - 5 } & $\begin{array}{c}\text { Filament } \\
\text { Stove-3 }\end{array}$ & $\begin{array}{c}\text { Filament } \\
\text { Stove-5 }\end{array}$ & $\begin{array}{c}\text { Induction } \\
\text { Stove-500 }\end{array}$ & $\begin{array}{c}\text { Induction } \\
\text { Stove-1300 }\end{array}$ \\
\hline Boiling water (1 liter) & 45 & 19 & 8 & 4 \\
Frying nuggets & 30 & 15 & 6 & 3 \\
\hline
\end{tabular}




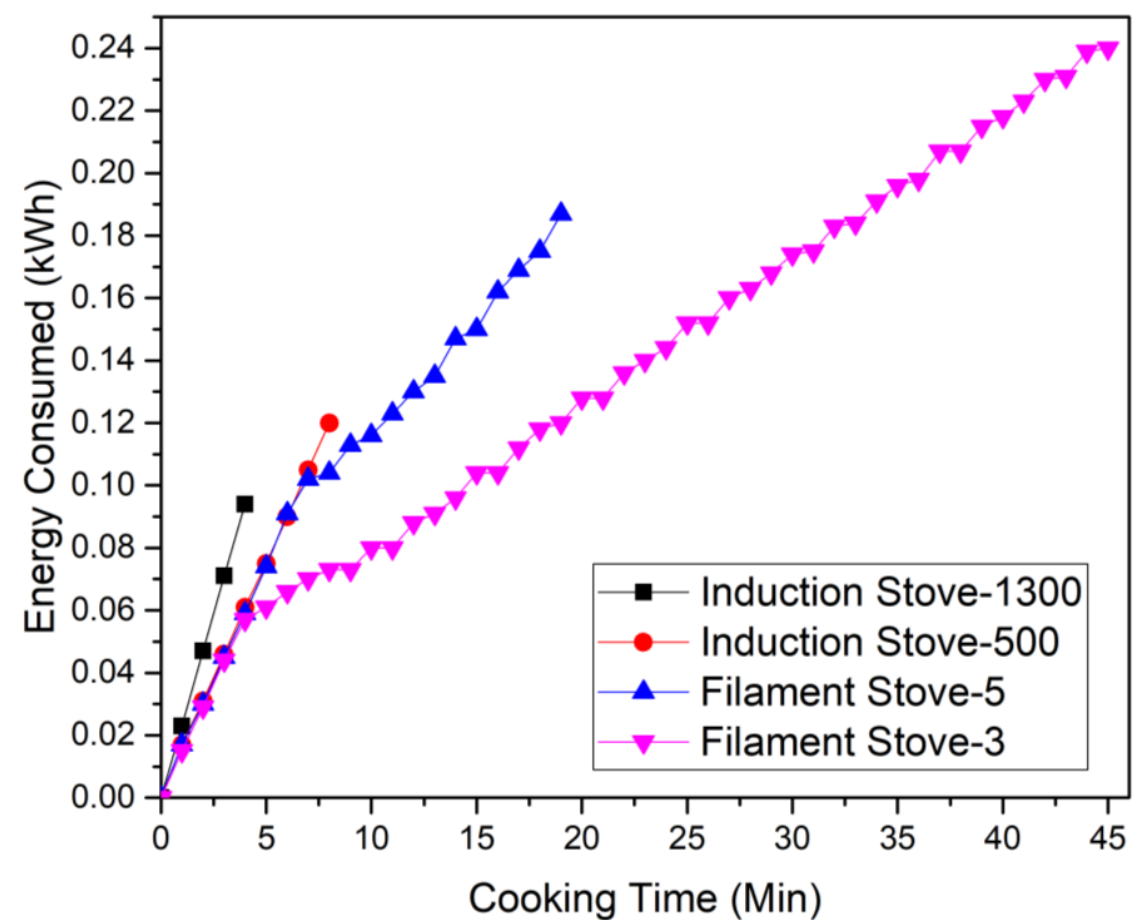

(a)

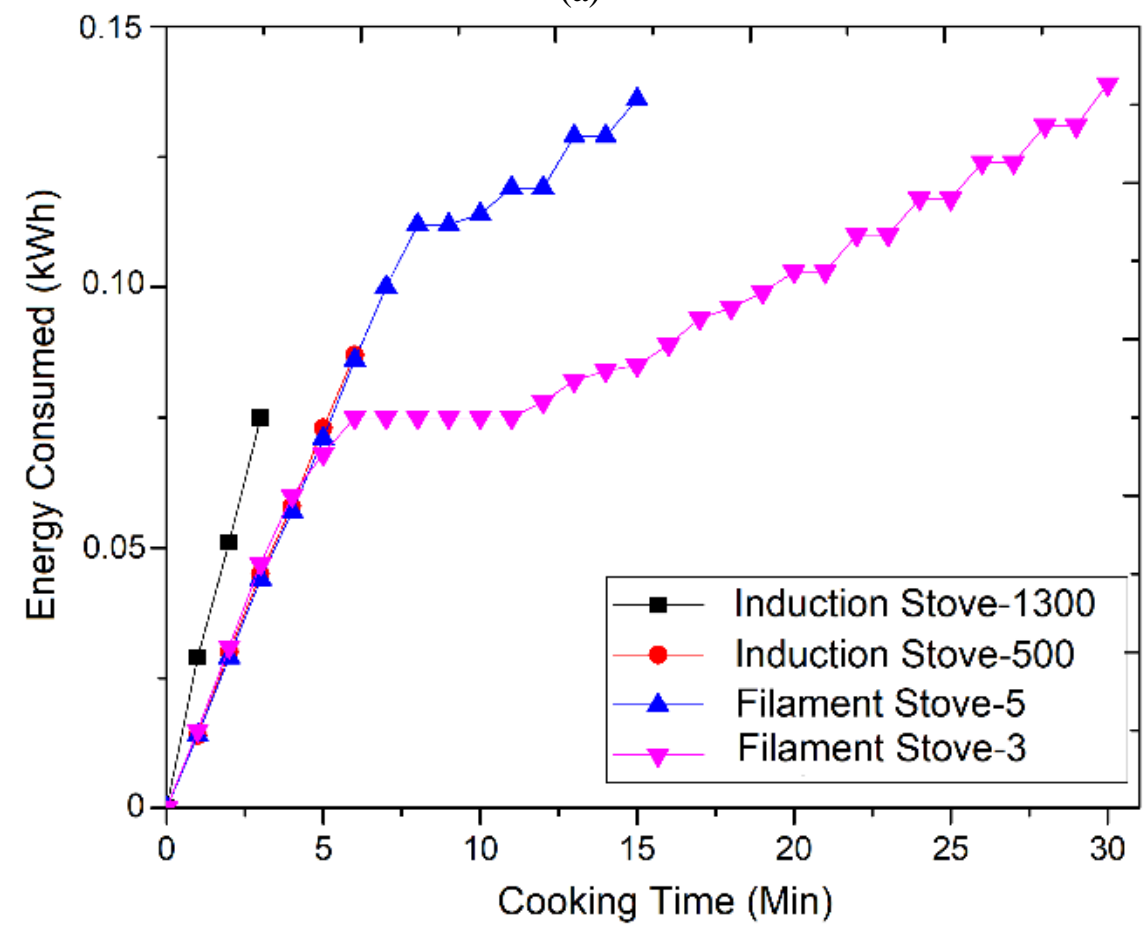

(b)

Figure 3. Comparison of electrical energy consumed by induction cooker and filament electric stove for (a) boiling water and (b) frying nuggets

Figure 3 (a), a comparative graph of the electrical energy consumed by an induction stove and a filament stove, is presented when boiling one liter of water. It appears that the slope of the curve for increasing the energy consumed by the induction stove is sharper than the filament electric stove. However, because the cooking time using an induction cooker is faster than that of a filament electric stove, the total energy consumed by an induction cooker to boil one liter of water is lower than that of a filament electric stove. In 
addition, it also appears that the curve of increasing energy consumption for filament electric stoves changes the slope pattern when heating is carried out above five minutes (for scale 3) and above 7 minutes (for scale 5). It is related to the achievement of close to the desired heating temperature so that the filament stove system will regulate the next energy or power consumption. An induction stove with a medium heating level $\left(500^{\circ} \mathrm{C}\right)$ consumes $0.12 \mathrm{kWh}$ of energy to boil one liter of water. An induction stove with a high heating rate $\left(1300^{\circ} \mathrm{C}\right)$ consumes $0.094 \mathrm{kWh}$ of energy, while a filament electric stove with a scale of 5 consumes energy of $0.187 \mathrm{kWh}$, and a filament electric stove with a scale of 3 consumes energy of $0.24 \mathrm{kWh}$. If the initial temperature of the water is $26^{\circ} \mathrm{C}$, then the energy required to boil one liter of water until it boils is $0.086 \mathrm{kWh}$. Thus, the efficiency of induction cookers with heating levels of 1300 and 500 and filament stoves with heating levels of 5 and 3 is $91.5 \%, 71.7 \%, 46 \%$, and $35.8 \%$, respectively. The same pattern also occurs in the process of frying nuggets. It can be seen that the induction stove at heating levels of $500^{\circ} \mathrm{C}$ and $1300^{\circ} \mathrm{C}$ consumes electrical energy of $0.087 \mathrm{kWh}$ and 0.075 $\mathrm{kWh}$, respectively. The filament electric stove with heating scales 3 and 5 respectively consumes $0.139 \mathrm{kWh}$ of electrical energy and $0.136 \mathrm{kWh}$. These results confirm that using an induction stove in the cooking process with the frying method is more efficient than the filament electric stove. This result was in agreement with the researches conducted by Hasanah and Handayani, ${ }^{16}$ and Gomez. ${ }^{18}$ In addition, it also appears that the cooking process using an induction stove with a high heating rate has the highest efficiency compared to the others. Through the measurement results of the electrical energy consumed, the cost of using electricity on the two electric stoves tested can be calculated. Because electric stoves require a large amount of power, the majority of Indonesian people who can use electric stoves are people who belong to the power limit $>1000 \mathrm{VA}$. The cost of the basic electricity tariff in 2020 (October - December) is $1,444.70 \mathrm{kWh}$. Therefore, the cost to boil one liter of water for an electric stove with a scale of 3 and 5 is Rp. 346.7 and Rp. 270.2. The cost for an induction stove to boil one liter of water at heating levels of $500^{\circ} \mathrm{C}$ and $1300^{\circ} \mathrm{C}$ is Rp. 173.4 and Rp. 135.8. For the process of frying nuggets, electric filament stoves with a scale of 3 and 5 each cost Rp. 200.8 and Rp. 196.5 while the induction cooker at heating levels of $500^{\circ} \mathrm{C}$ and $1300^{\circ} \mathrm{C}$ costs Rp. 125.7 and Rp. 108.3. Therefore, it is clear that the cost of cooking using an induction stove is relatively cheaper than a filament electric stove.

Figure 4 shows $\mathrm{CO}_{2}$ emitted in boiling water and frying nuggets using a filament electric stove and an induction stove. It appears that the amount of $\mathrm{CO} 2$ detected fluctuates around $400-500 \mathrm{ppm}$, and it indicates that the $\mathrm{CO}_{2}$ emissions produced in the cooking process using both electric stoves are not significant. It is because the detected $\mathrm{CO}_{2}$ value is not too far from the background $\mathrm{CO}_{2}$ level. The measurement results are much lower than $\mathrm{CO}_{2}$ emissions on LPG stoves, reaching $2000 \mathrm{ppm}$ when used for cooking ${ }^{18}$. In addition, the measurement of $\mathrm{CO}$ emission levels in the cooking process using the two stoves is very low, even reaching $0 \mathrm{ppm}$. Therefore, switching LPG stoves to electric stoves, both filament electric stoves and induction cookers, is an excellent program to reduce carbon emissions in the cooking process. A number previous research conducted by Gomez et $\mathrm{al}^{18}$ and Ramirez et $\mathrm{al}^{19}$, also supported this result as they indicated in their research paper. The result of this research support the use of induction and filament stove in applying the policy of zero emission. 


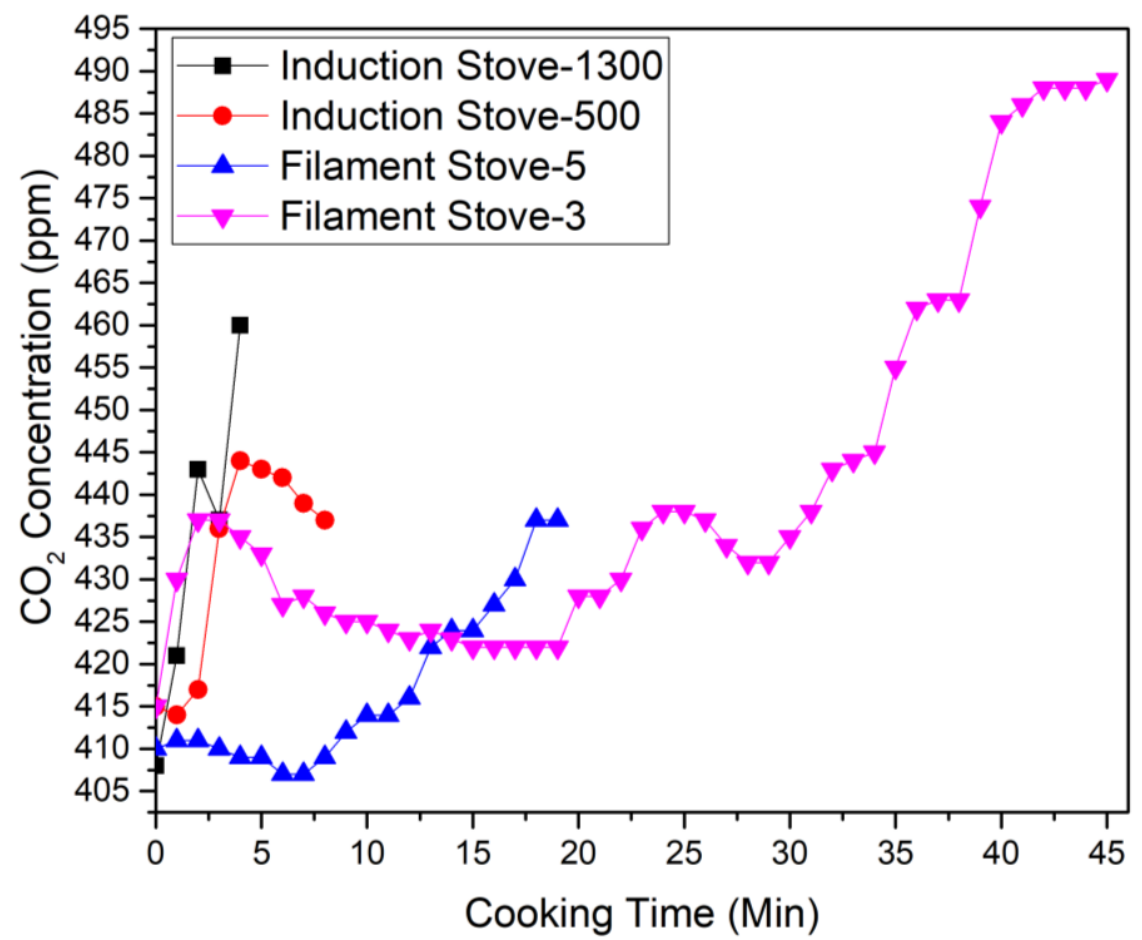

(a)

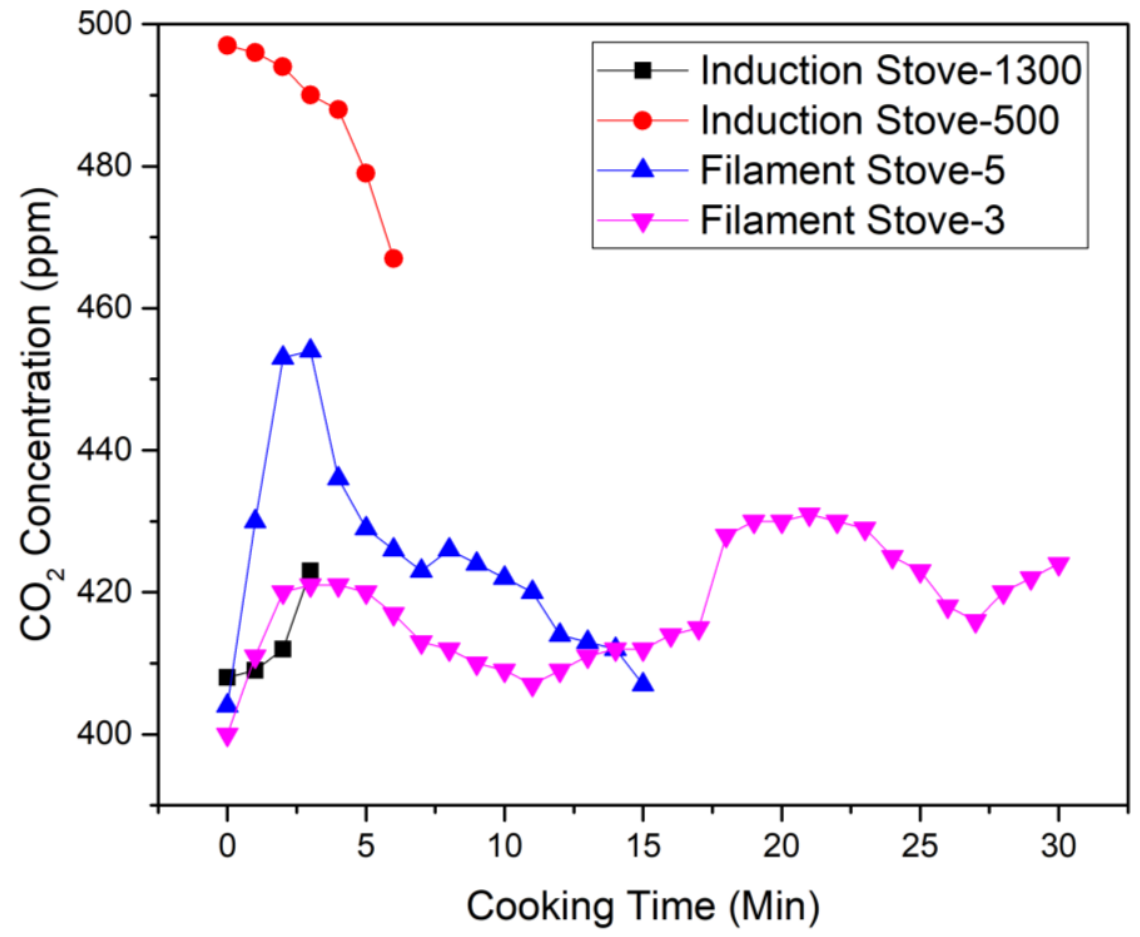

(b)

Figure 4. Comparison of $\mathrm{CO}_{2}$ emissions by induction stove and filament electric stove for (a) boiling water and (b) frying nuggets

\section{Conclusion}

Based on the study, it can be concluded that induction stoves have higher energy efficiency compared to filament electric stoves. In addition, it also appeared that the higher heating rate for both types of stoves also has higher efficiency and relatively low carbon emission compared to the LPG stoves. 
To achieve the target of using induction cookers, we proposed several recommendations:

1. The use of enormous power in operating the induction stove will specifically be challenged for the government since most of households still use electrical energy provided by PT. PLN.

2. It is needed to promote the use of the induction stoves rather than the LPG stoves in order to support the program for reducing carbon emission.

\section{References}

1. Reza I. and Yulianto D. Evaluasi terhadap karbon di dunia maju dan berkembang: sebuah usaha dalam kebijakan pembangunan lingkungan. PARADIGMA: Jurnal Ilmu Administrasi. 2017; 4(1): 113-138.

2. Tiandho Y., Afriani F., and Puriza M. An explicit model of temperaturedependent thermal conductivity for nanofluids. IOP Conference Series: Earth and Environmental Science. 2019; 353(1): 012013.

3. Firdaus F. Jejak Karbon Sektor Energi DI Yogyakarta dan Rekomendasi Jumlah Pohon yang Harus Ditanam untuk Reduksi Emisi Gas $\mathrm{CO}_{2}$. Asian Journal of Innovation and Entrepreneurship. 2019; 4(1): 2332.

4. Handayani T., Hulukati S., Jaya R., Tiandho Y., and Abdullah R. The prototype of solar-powered building lighting IoT. IOP Conference Series: Material Science and Engineering. 2019; 486: 012079.

5. Sugiawan Y. and Managi S. The environmental Kuznets curve in Indonesia: Exploring the potential of renewable energy. Energy Policy. 2016; 98: 187-198.

6. Maulidia M., Dargusch P., Ashworth P., and Ardiansyah F. Rethinking renewable energy targets and electricity sector reform in Indonesia: A private sector perspective.
Renewable and Sustainable Energy Reviews. 2019; 101: 231-247.

7. Shezan S., Al-Mamoon A., and Ping $\mathrm{H}$. Performance investigation of an advanced hybrid renewable energy system in Indonesia. Environmental Progress \& Sustainable Energy. 2018; 37: 1424-1432.

8. Nugrahayu Q., Nurjannah N., and Hakim, L. Estimasi emisi karbondioksida dari sektor permukim di Kota Yogyakarta menggunakan IPCC guidelines. Jurnal Sains dan Teknologi Lingkungan. 2017; 9(1): 25-36.

9. Badan Pusat Statistik. Badan Pusat Statistik. [Internet]. 2017. Available from:

https://www.bps.go.id/statictable/201 4/09/10/1364/persentase-rumahtangga-menurut-provinsi-dan-bahanbakar-utama-untuk-memasak-tahun2001-2007-2016.html.

10. PPID Provinsi Jawa Barat. PPID Provinsi Jawa Barat. [Internet]. 2019. Available from: http://ppid.jabarprov.go.id/posting/re ad/1479-Jabar-Provinsi-PertamaKonversi-Kompor-Gas-ke-Listrik.

11. Wiratmini N. P. E. Pemerintah kaji peluang konversi LPG ke kompor listrik. [Internet]. 2019. Available from:

https://ekonomi.bisnis.com/read/201 90506/44/919130/pemerintah-kajipeluang-konversi-lpg-ke-komporlistrik-.

12. Martínez-Gómez J., Ibarra D., Villacis S., Cuji P., and Cruz P.R. Analysis of LPG, electric and induction cookers during cooking typical Ecuadorian dishes into the national efficient cooking program. Food Policy. 2016; 59: 88-102.

13. Gould C., Schlesinger S., Toasa A., Thurber M., Waters W., Graham J., and Jack D. Government policy, clean fuel access, and persistent fuel stacking in Ecuador. Energy for 
Sustainable Development. 2018; 46: 111-122.

14. Banerjee M., Prasad R., Rehman I., and Gill B. Induction stoves as an option for clean cooking in rural India. Energy Policy. 2016:88; pp. 159-167

15. Istardi D. and Triwinarko A. Induction heating process design using COMSOL Multiphysics software. Telkomnika. 2011; 9(2): 327-334.

16. Hasanah A. and Handayani O. Perbandingan efisiensi energi dan biaya pada kompor induksi terhadap kompor listrik dan kompor gas. Jurnal Sutet. 2016; 6(2): 22-29.

17. PT. PLN (Persero). Statistik PLN 2018. Jakarta: Sekretariat Perusahaan PT. PLN (Persero); 2018.

18. Gomez J., Ibarra D., Villacis S., Cuji P., and Cruz P. Analysis of LPG, electric and induction cookers during cooking typical Ecuadorian dishes into the national efficient cooking program. Food Policy. 2016; 59: 88102.

19. Ramirez, A. D., Perez, E. F., Boerom A. J., and Salas, D. A. Carbon Footprint of Energy Systems: Liquefied Petroleum Gas Based Cooking vs Electricty Based Cooking in Ecuador. ASME International Mechanical Engineering Congress and Exposition. 2017; 58417: V006T08A061. 